\title{
Environmental Impacts to Residual Stand Damage due to Logging Operations in Hyrcanian Forest
}

\author{
Meghdad JOURGHOLAMI \\ University of Tehran, Faculty of Natural Resources, Department of Forestry and Forest \\ Economics,Zob-e-AhanStreet, Karaj, Iran;mjgholami@ut.ac.ir
}

\begin{abstract}
The development of harvesting systems aims to provide physically feasible, economically viable, and environmentally sound solutions. Residual stand-damage data have been collected from a mixed broadleaved stand in Kheyrud area in Hyrcanian forest in the northern of Iran. After the harvesting operations, for all trees, damage to the bole, roots, extent of the damage, wounding patterns, size and distribution was assessed using stratified systematic sampling with a random start and fixed area plots. Results show that wounding occurred on $16.4 \%$ of the remaining trees, but the severity of wounding varied significantly by species. Forty-six percent of wounding for all species combined was considered as small size. The greatest average amount of damage, to a bole, occurred along the first $1 \mathrm{~m}$ up from the ground and also within $3 \mathrm{~m}$ of the skid trail centerline (86.4\%). Gouges were present on $79 \%$ of all scars. The stratification of the study unit would effectively improve accuracy of stand damage surveys. Selection of the appropriate method for damage reduction to trees adjacent skid trails was crucial. According to the results, skidding damage cannot be completely avoided in practice. We suggest that the education and the entertainment of the foresters and workers in forest would be enhanced and the injuries could be explained before the harvesting to the workers. In such a way the damages would be less in the future.
\end{abstract}

Keywords: Kheyrud forest, forest harvesting, residual stand damage, skid trail, stratification

\section{Introduction}

Managed forests based on ecological principles are able to continually provide products and services and this type of management, as well as economically, especially in the long term would be cost-effective. Ecological stability of forest stands with sufficient and appropriate to the species richness and according to their natural condition is fundamental issues of forest ecosystem management. So it is essential that ecological considerations such as follow the natural ecosystems of forests, reduce the damage and avoid exploitation of vulnerable areas combined with harvesting operations (Dykstra and Heinrich, 1996; Heinemann, 2004). At most harvesting systems, a type of scarring and damage of trees was a common type, caused by the harvesting and wood extraction. Damage to residual stand was caused by pests' attack and pathogenic fungi on tree trunk and meanwhile the development of decay, reduced growth of trees in the forest stand (Youngblood, 2000). There are many documents about residual stand damage following forest operation and performance of different skidding systems. Each harvesting systems has a specific damage on forest trees and regeneration (Vasiliauskas, 2001).

The evaluated tree species are not equally susceptible to mechanical damages (Yilmaz and Akay, 2008). Damage to residual stand in forest operations often occur during the timber extraction (Froese and Han, 2006; Han, 1998; Kosir, 2008; Vasiliauskas, 1993). Trees were damaged by skidders and timber which extracted (Siren, 1982). Most of the resulting wounds occurred at or near the base of a tree (Athanassiadis, 1997; Han, 1998; Han and Kellogg, 2000). Logging wounds varied in size to a great extent. In North American conifers, scar sizes on damaged trees ranged from 0.13 to $2976.8 \mathrm{~cm}^{2}$ (Bettinger and Kellogg, 1993). Most trees wounded due to forest operations were not randomly distributed within a stand, but situated close to the extraction trails (Froese and Han, 2006; Youngblood, 2000). Damage to residual trees was related to several variables besides the logging system, including species (Sidle and Laurent, 1986; Youngblood, 2000), thinning intensity (Benson and Gonsior, 1981), planning and layout (Fairweather, 1991), tree distance from skid trails (Bettinger and Kellogg, 1993), tree size (Ostrofsky et al., 1986), and skid trail spacing (Vasiliauskas, 2001). In contrast, relatively few published studies examined the methods to assess the residual stand damage (Han and Kellogg, 2000). Stehman and Davis (1997) reported that a sampling strategy for the harvest region is divided into two strata: the area near and outside the skid trails. The authors by using hypothetical data proved that under certain forest conditions stratify sampling strategy in achieved likely to more accurately estimate to the damage in comparison with simple random sampling method.

Froese and Han (2006) studied the damage of residual trees to conifer mixed stand and concluded that $37.4 \%$ of the residual stands were damaged. Also, $84 \%$ of scars in 
66

all species were less than $194 \mathrm{~cm}^{2}$ and $67 \%$ of damage to trees was the first $2 \mathrm{~m}$ of boles. Also, $68 \%$ of the injuries were occurred within the range of $4 \mathrm{~m}$ from the skid trail central line. Gouges, included $41 \%$ of all damaged. Han (1998) compared different sampling methods to assess the damage to residual stand and introduced systematic random sampling method as the best method for estimating damage to residual stand. Fecklin et al. (1997) concluded that skidding operations, with rubber-tired skidder, caused damage at about $22 \%$ of remaining trees.

Different studies about the damage to the residual stand have been conducted in Iran (Hosseini, 1994; Mousavi, 2009; Naghdi, 2004; Nikooy, 2007; Rashidi, 1995). Hosseini (1994) studied the first research in this field about residual stand damage in north of Iran and results showed that gouges and large scar size mostly associated with activities of the wood extraction. $82.5 \%$ of scars were occurred at $2 \mathrm{~m}$ boles. This study was designed with the following objectives: to assess and to measure the damage after logging along winching strips and skid trails, to compare the characteristics of stand damage.

\section{Materials and methods}

\section{Study site}

The research was carried out in compartment no. 208, in Namkhaneh District within Kheyrud Educational and Research Forest in the Hyrcanian forest region in the north of Iran. The altitude ranged between 830-1150 $\mathrm{m}$ and the forest lying on a southwestern aspect. The slope on these sites ranged from 15 to $50 \%$ with an average of 30 percent. An average rainfall ranged from 1420 to $1530 \mathrm{~mm}$ /year, with the heaviest precipitation occuring in the summer and fall. This area was dominated by natural forests containing native mixed deciduous tree species such as Fagus orientalis Lipsky, Carpinus betulus L. and Acer velutinum Boiss. The management method is mixed un-even aged high forest with single and group selective cutting regime. Trees to be removed were felled, limbed and topped motor-manually. Felled trees were bucked and processed with chainsaws into logs, sawn-lumber and pulpwood. The logs with 5-25 $m$ length were extracted by wheeled cable skidders to the roadside landings. The fuel wood was extracted by mules. The field study was conducted from August to September 2010 in Kheyrud Forest. The compartment area, tree per hectares and volume per hectares were 31.3 ha, 282, 403 $\mathrm{m}^{3}$, respectively. Also, total removed tree and volume of removed tree were 153 and $720 \mathrm{~m}^{3}$, respectively.

\section{Experimental design and data collection}

To access the extent of injury, pattern, size and distribution of damages following skidding with rubber-tired skidder (Timberjack $450 \mathrm{C}$ ), systematic-random and stratification sampling method was used in the skidded area. In the stratified sampling method, the sample plots without damage were excluded from the analysis; thereby the accuracy of inventory of the damage has been im- proved. Due to the scattering of the marked trees because of single selection systems and in order to reduce the inventory errors, network inventory dimensions of $25 * 25 \mathrm{~m}$ was used. To determine the amount of damage to standing trees, plots with a sample area of 5, 3 and $1 \mathrm{R}(500,300$ and $100 \mathrm{~m}^{2}$ ) were taken and implemented (Fig. 1).

Intensity of inventory to determine the severity of damage in a systematic random sampling method, given

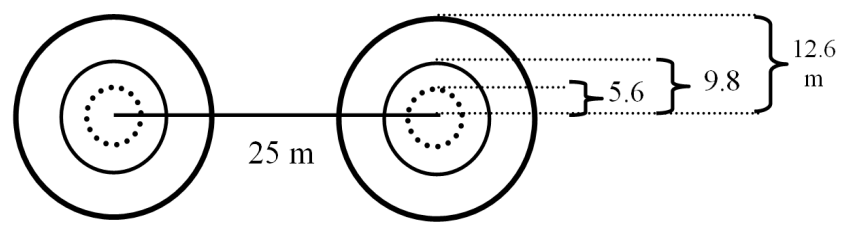

Fig. 1. Dimensions of inventory network and size of sample radius plots used to assess damage

the size and area of a sample network, were 80,48 , and $16 \%$, respectively. Due to the scattering of marked trees in the Parcel, inventory network was randomly implemented in the area. In this study, a total of 57 sample plots with $1 \mathrm{R}$ area, 70 sample plots with $3 \mathrm{R}$ area, 78 sample plots with $5 \mathrm{R}$ area, and totally 78 plots of 469 sample plots have been included in damaged class.

\section{Residual damage to regeneration along winching strips}

Residual damage along winching strips and skid trails was assessed in 208 compartments. Damage to the residual stand along the winching strip was studied in sites randomly located within the study area. Species and DBH were recorded for all trees along the winching strips and skid trails and each tree was examined for any kind of damage. All injured saplings and trees with a DBH $>10 \mathrm{~cm}$ were measured and recorded, and classified according to 3 main classes of damage: 1) one wound per tree; 2) 2-3 wounds per tree; 3 ) more than 3 wounds per tree. In addition, total number, diameter and tree species around the skid trails and winching strips, total damaged trees, location of wound (s) on each tree (on roots, up to $1 \mathrm{~m}$, above $1 \mathrm{~m}$ ), size of wounds (less than $500 \mathrm{~cm}^{2}$, between $500-1000 \mathrm{~cm}^{2}$ and more than $1000 \mathrm{~cm}^{2}$ ) and degree of injuries (deep and light) were recorded.

\section{Results and discussion}

\section{Analysis of the network sample}

A total of 622 trees measured in a sample, 520 safe trees and 102 trees were damaged. In other words, $16.4 \%$ of forest trees were injured after skidding operation. Analysis of data showed that on average there were 9 trees in each plot of $5 \mathrm{R}\left(500 \mathrm{~m}^{2}\right)$ area that the averages of damaged trees in 1 tree per sample plot. Tab. 1 shows the statistical parameters to analyze the sample plots.

The percentages of damage trees in sample plot of $1 \mathrm{R}$ $\left(100 \mathrm{~m}^{2}\right), 3 \mathrm{R}\left(300 \mathrm{~m}^{2}\right)$ and $5 \mathrm{R}\left(500 \mathrm{~m}^{2}\right)$ area were $23,15.8$ and 5 percent. By increasing sample size, the number of damaged trees to sample size was decreased and the time 
Tab. 1. Statistical parameters to analyze the sample plots

\begin{tabular}{lccccccccc}
\hline \multirow{2}{*}{ Factor } & \multicolumn{3}{c}{$\begin{array}{c}\text { Total } \\
\text { trees }\end{array}$} & \multicolumn{3}{c}{$\begin{array}{c}\text { No damaged } \\
\text { trees }\end{array}$} & \multicolumn{3}{c}{$\begin{array}{c}\text { Damaged } \\
\text { trees }\end{array}$} \\
\cline { 2 - 11 } & $1 \mathrm{R}$ & $3 \mathrm{R}$ & $5 \mathrm{R}$ & $1 \mathrm{R}$ & $3 \mathrm{R}$ & $5 \mathrm{R}$ & $1 \mathrm{R}$ & $3 \mathrm{R}$ & $5 \mathrm{R}$ \\
\hline Total & 309 & 454 & 622 & 238 & 360 & 520 & 71 & 94 & 102 \\
Average & 5.4 & 6.78 & 8.9 & 4.2 & 5.42 & 7.56 & 1.2 & 1.37 & 1.35 \\
Max. & 10 & 18 & 25 & 7 & 14 & 24 & 3 & 4 & 4 \\
Min. & 3 & 3 & 3 & 2 & 2 & 2 & 1 & 1 & 1 \\
St. De. & 1.54 & 3.03 & 5.84 & 1.11 & 2.6 & 5.76 & 0.54 & 0.67 & 0.57 \\
St. De. Err. & 0.2 & 0.38 & 0.74 & 0.15 & 0.33 & 0.73 & 0.07 & 0.08 & 0.04 \\
Inventory Err. & 7.41 & 11.04 & 16.2 & 6.97 & 11.87 & 18.8 & 5.69 & 7.02 & 10.6 \\
\hline
\end{tabular}

and cost of plot measuring were increased. Based on the results, the sample plot of $3 \mathrm{R}\left(300 \mathrm{~m}^{2}\right)$ area was the best sample size to calculate the amount of damage to residual trees.

\section{Damage to residual stand}

Measurement of trees, damaged in the skid trail, showed that 102 trees were damaged from some degree of injury. $62 \%$ of the hornbeam trees (Carpinus betulus) were damaged, beech (Fagus orientalis) and other species were consisting of $24 \%$ and $14 \%$ of damaged trees, respectively. The results showed that the most of damaged trees are related to $40-20$ and $70-40 \mathrm{~cm}$ diameter class of trees. In the other hands, valuable trees were suffering from some degree of damage (Fig. 2b). The study of the height in case when scar on tree trunk showed $75 \%$ of wounds, located within $1 \mathrm{~m}$ from the ground on the bole, $18 \%$ on roots
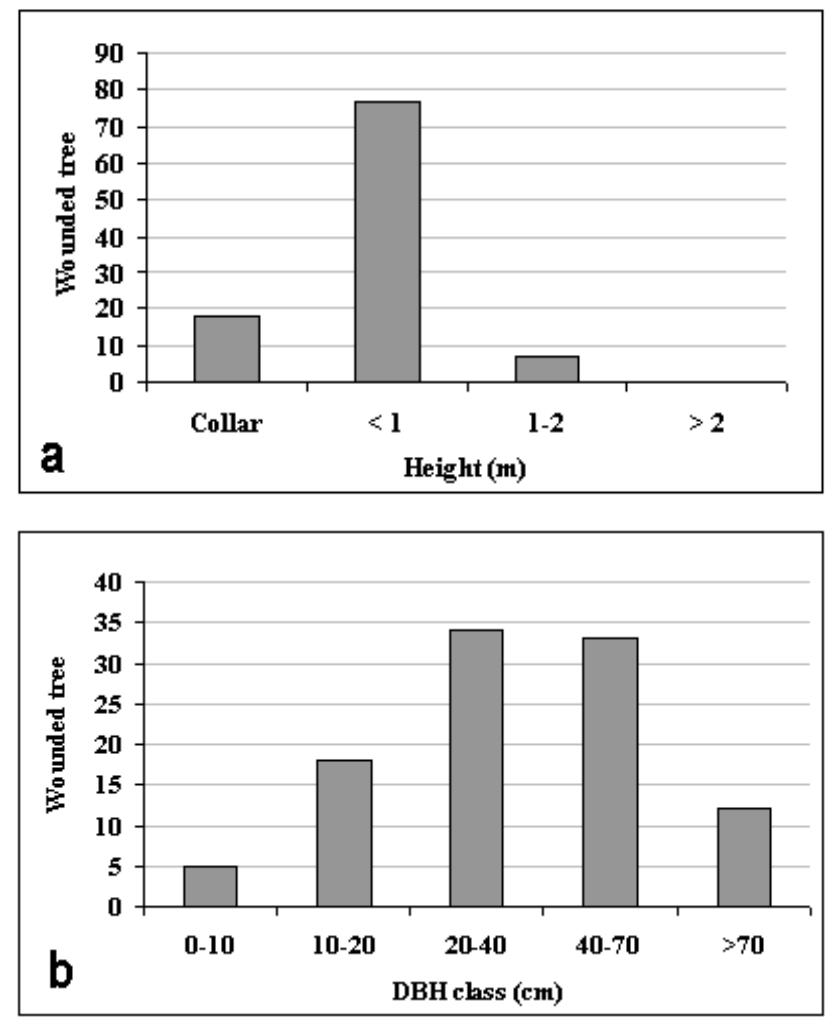

Fig. 2. Number of wounded tree as a function of height of wound in the bole (a) and DBH class (b)
67

and $1 \%$, located above $1 \mathrm{~m}$ (Fig. 2a). However, there is no wound on $2 \mathrm{~m}$ above the trunk and about $93 \%$ of wounds showed at the first $1 \mathrm{~m}$ of tree trunk.

Study of the scars' severity showed that $21 \%$ were superficial and $71 \%$ of them were deep, with damage to the cambium (Fig. 3), and only $8 \%$ of wounds were very deep (damage to tree wood, including wood Split).

The results about the wounds area in tree trunk showed that $46 \%$ of the scars were smaller than $500 \mathrm{~cm}^{2}, 29 \%$ between 500 and $1000 \mathrm{~cm}^{2}$, and $25 \%$ larger than $1000 \mathrm{~cm}^{2}$ (Fig. 4). Wound by at least $42 \mathrm{~cm}$ and the maximum was $2319 \mathrm{~cm}^{2}$. The average wound size of each tree was 508 $\mathrm{cm}^{2}$. Wounds on the class, less than $500 \mathrm{~cm}^{2}$, the average wound per tree was $271 \mathrm{~cm}^{2}$, while the minimum and maximum area of each tree wounds in this group were 42 and $468 \mathrm{~cm}^{2}$ respectively. Wounds on the class between $500-1000 \mathrm{~cm}^{2}$, the average wound per tree was $688 \mathrm{~cm}^{2}$ and minimum and maximum area of each tree wounds in this group were 935 and $508 \mathrm{~cm}^{2}$, respectively. Wounds on the class, more than $1000 \mathrm{~cm}^{2}$, the average wound per tree was $1395 \mathrm{~cm}^{2}$, while minimum and maximum area of each tree wounds in this group were 2319 and $1001 \mathrm{~cm}^{2}$, respectively.

Overall, in this study, $30 \%$ of damaged trees had one wound per bole, $67 \%$ had $1-3$ wounds, and $3 \%$ had more than 3 wounds per bole. Overall, $70 \%$ of the trees have more than one wound (Fig. 5).

Results showed that $58 \%$ of the total damage to the trees related to skidding and $42 \%$ was related to winch-

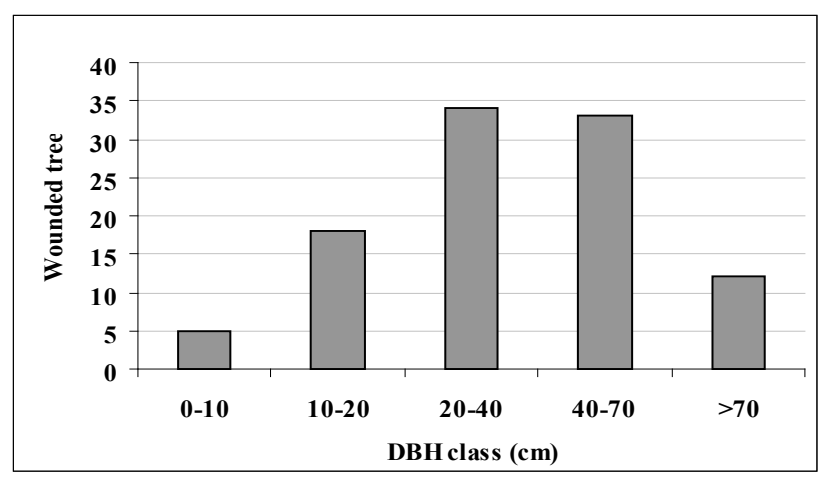

Fig. 3. Number of wounded tree related to degree of wound

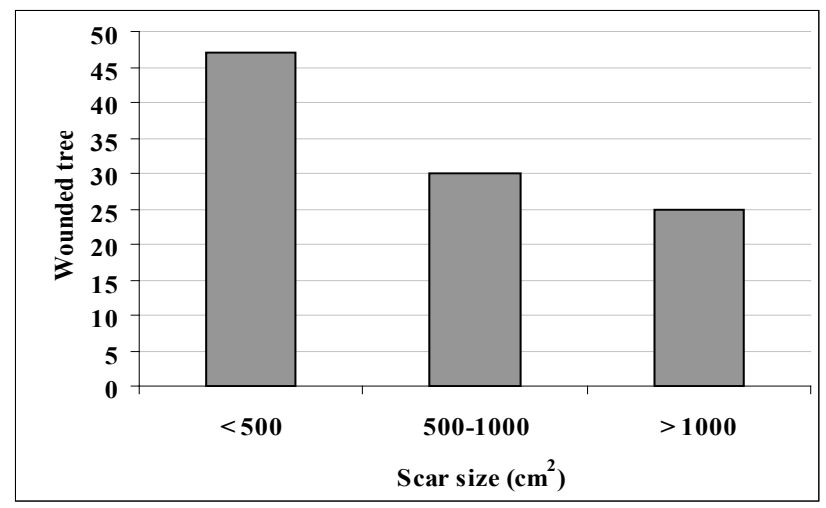

Fig. 4. Number of wounded tree related to scar size 
68

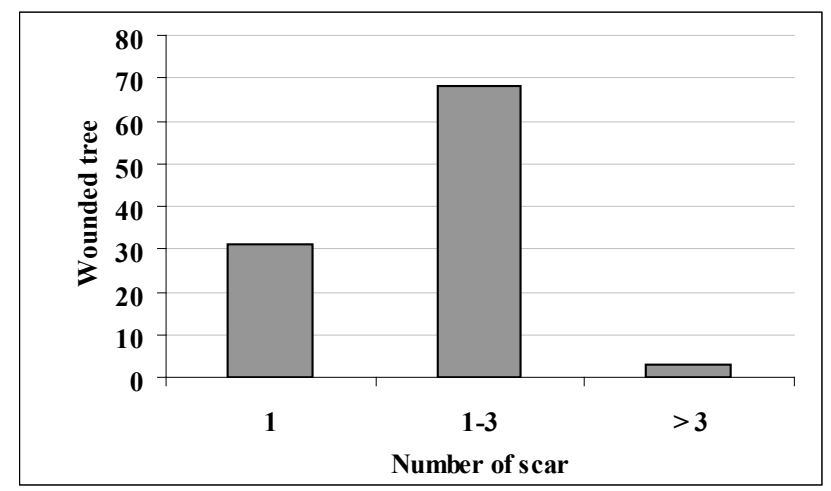

Fig. 5. Number of wounded tree and number of scar

ing. In other words, more than one third of the damage to trees occurred in the winching stage that the main reasons were the incorrect directional tree felling and inappropriate choice of winching routes. Many trees damaged in the skidding operation were not randomly dispersed in the forest stand and located near skid trails. With increasing distance from the center of skid trails, the number of damaged trees was reduced (Fig. 6). The majority of the damage (86.4\%) occurred within $3 \mathrm{~m}$ of the skidder centerline. At distances of 3 to $4 \mathrm{~m}$, the occurrence of scarring was $10.2 \%$ of the total; only $3.4 \%$ of the damage was found more than $4 \mathrm{~m}$ from that line. The average distance of damage tree was 2.56 meters from the center line of skid trails and maximum and minimum of damaged trees were 4.5 and $1.7 \mathrm{~m}$ away from the center line of skid trails, respectively. The highest concentration of damaged trees was in the distance of less than $3 \mathrm{~m}$ and $97 \%$ of damaged trees were in less than 4 meters distance from the center of skid trails.

In this study, systematic random sampling method was used with stratification that with acceptable accuracy and ease of implementation and this result is consistent with Han and Kellogg (2000) research. In order to estimate the residual damage caused by the thinning, the researchers were compared four methods in pine stands in West Oregon. They found that there were significant differences in the ease and simplicity of these methods were imple-

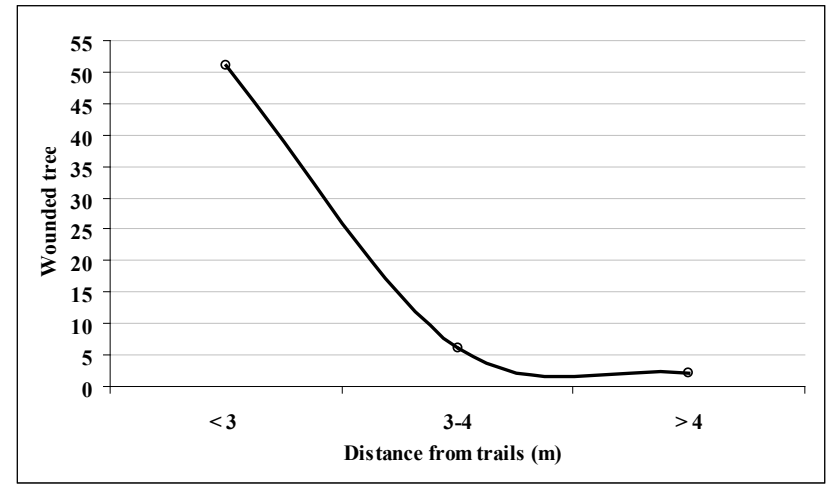

Fig. 6. Number of wounded tree as a function of distance from the centerline of a 3-m-wide skidder trail mented and demonstrating a systematic random sampling method, the simplest to be used. Beech and hornbeam were included in more than $86 \%$ of damaged trees. The high percentage of damage of these two species in the skidding operations wasn't due to the sensitivity of these species to mechanical damage from timber extraction, but primarily related to the dominant presence of these species in this forest. Although the percentage of damage to remaining trees in this study was far less than the other similar internal and external studies. Of course, this study only was considered the amount of damage to the trees related to skidding, and considering the damage caused by tree felling, the damage will be far greater. Froese and Han (2006) estimated damage to residual stand to $37.4 \%$; Fecklin et al. (1997) between 22\% to 47\%; Naghdi (2004) to $19.04 \%$ and Nikooy (2007) to $23.5 \%$.

About $33 \%$ of damaged trees to $20-40 \mathrm{~cm}$ diameter class and $32 \%$ of trees were related to the class of $40-70$ $\mathrm{cm}$. The results showed that with increasing diameter, the percentage of damaged trees was decreased and the loss to follow the reduction in the number of trees as diameter was increased in the uneven-aged forest stand. The findings of this study were consistent with the results of Hosseini (1994), Naghdi (2004) and Nikooy (2007) that the highest percentage of damaged trees has been measured in diameter classes less than $30 \mathrm{~cm}$. Also, importance of this classification was important because in the uneven-aged stand, young and middle-aged trees have a determining role in forest growth and in the selective forestry systems trees were left for many years in stands to do its role in the stands. The secondary factors have been caused to the development of mechanical damage to trees and caused to reduce growth and potential value of forest stand. In this study, about $93 \%$ of wounds occurred at or near the first $1 \mathrm{~m}$ of tree trunk. The importance of the classification of wounds in the base of a tree was that the base of tree was the most valuable part of the tree trunk and was reduced the value of timber in the next harvests. The findings of this study were similar to previous research conducted in this area trees (Han, 1998; Froese and Han, 2006; Mousavi, 2009; Stehman and Davis, 1997). However, Naghdi, (2004) and Nikooy (2007) expressed that the most of the wounds were in the above $2 \mathrm{~m}$ of tree trunk.

The results show that more than $50 \%$ of wounds per tree have with an area of more than $500 \mathrm{~cm}^{2}$ that these wounds rarely have been closed and healed. Froese and $\mathrm{Han}$ (2006) concluded that $84 \%$ of wounds in the all species were much less than $194 \mathrm{~cm}^{2}$. Since logging injury usually occurs on the lower part of a trunk, wound decay in a tree affects the most valuable timber (Vasiliauskas, 2001). Although, the results of this study did not match with those of Hosseini (1994) and Nikooy (2007). They expressed the highest percentage of wounds have the area less than $100 \mathrm{~cm}^{2}$. The severity of the wounds indicated that $80 \%$ of the wounds were deep, with damage to the cambium that was consistent with Sidle and Laurent (1986) results. 
With increasing distance from the center line of skid trails, the numbers of damaged trees have been reduced that the findings of this study was similar to previous research results (Han, 1998; Youngblood, 2000; Yilmaz and Akay, 2008). In addition, Hosseini (1994), Naghdi (2004) and Nikooy (2007) concluded that there was strong correlation between the percentage of damaged trees and increase the distance from the skid trails.

\section{Conclusions}

Selection of the appropriate method for damage reduction to trees adjacent skid trails was crucial. According to the results, skidding damage cannot be completely avoided in practice. Therefore, to minimize wounding in this forest stand, a number of the suggestions have been proposed. The description of the wounded trees and reasons for that were done with very interesting details, but we suggest that the education and the entertainment of the foresters and workers in forest would be enhanced and the injuries could be explained before the harvesting to the workers. In such a way the damages would be less in the future. Timber extraction should be completely suspended during the rainy climate and areas with steep terrain should be excluded from the skidding operations. It should also be used in a designated skid trails. In order to control wound infection by decay fungi, a number of wound dressings have been tested to prevent wound decay in forest stand. It is more appropriate to encourage the foresters to adopt methods which avoid damage to residual trees during logging operation. The authors hope that the results of this study will be used in order to optimal management of harvesting operation.

\section{References}

Athanassiadis D (1997). Residual stand damage following cutto-length harvesting operations with a farm tractor in two conifer stands. Silva Fenn 31(4):461-467.

Benson RE, Gonsior MJ (1981). Tree damage from skyline logging in western larch/Douglas-fir stands. International Forest and Range Experiment Station, USDA Forest Service, Research Paper INT-268.

Bettinger P, Kellogg LD (1993). Residual stand damage from cut-to-length thinning of second growth timber in the Cascade Range of western Oregon. Forest Prod J 43(1112):59-64.

Dykstra DP, Heinrich R (1996). FAO model code of forest harvesting practice. FAO. Italy. Rome.

Fairweather SE (1991). Damage to residual trees after cable logging in northern hardwoods. North J Appl For 8(1):1517.

Fecklin RL, Dyer JP, Cutter BF, Draper T (1997). Residual tree damage during selection cuts using two skidding system in the Missouri Ozarks, Univ of Missouri-Columbia, 64 p.

Froese K, Han HS (2006). Residual stand damage from cut-tolength thinning of a mixed conifer stand in northern Idaho.
West J Appl For 21(3):142-148.

Han HS, Kellogg LD (2000). A comparison of sampling methods for measuring residual stand damage from commercial thinning. Int J For Eng 11(1): 63-71.

Han HS (1998). Damage to young douglas-fir stand from commercial thinning with various timber harvesting systems and silvicultural prescriptions: characteristics, sampling strategy for assessment and future volume loss. Oregon State Univ, Depart of Forest Engineering, PhD Diss, 220 p.

Heinemann HR (2004). Forest operation under mountainous conditions. In: Burley J, Evans J, Youngquist J (Eds). Encyclopedia of Forest Sciences. Elsevier Academic Press, Amsterdam.

Hosseini SM (1994). Study of forest utilization impacts on residual stand in Darabkola forest, management plan. Univ Tarbiat Modarres, Fac Natural Resources, MSc Diss. 120 p.

Kosir B (2008). Damage to young forest due to harvesting in shelterwood systems. Croat J For Eng 29(2):141-153.

Mousavi R (2009). Comparison of productivity, cost and environmental impacts of two harvesting methods in Northern Iran: short-log vs. long-log. Univ Joensuu, Fac Forest Sciences, Finland, PhD Diss, 160 p.

Naghdi R (2004). Study of optimum road density in tree length and cut to length system. Univ Tarbiat Modarres, Fac Natural Resources, Iran, PhD Diss, 201 p.

Nikooy M (2007). Optimizing production cost and damage reduction to wood, trees and forest by harvest planning (case study: Asalem Forest District area). Tehran Unive, Natural Resources Fac, Iran. PhD Diss, 165 p.

Ostrofsky WD, Seymour RS, Lemin RC (1986). Damage to northern hardwoods from thinning using whole-tree harvesting technology. Can J For Res 16:1238-1244.

Rashidi R (1995). Effect of mechanical damages on Beech tree growth. Iran J Nat Res 47:58-70.

Sidle RC, Laurent TH (1986). Site damage from mechanized thinning in southeast Alaska. North J Appl For 3:94-97.

Siren M (1982). Stand damage in thinning operation with a grapple loader processor. Folia Forest 528:1-16.

Stehman SV, Davis CJ (1997). A practical sampling strategy for estimating residual stand damage. Can J Forest Res 27(10):1635-1644.

Vasiliauskas R (2001). Damage to trees due to forestry operations and its pathological significance in temperate forests: a literature review. Forestry 74(4):319-336.

Vasiliauskas R(1993). Wound decay of Norway spruce associated with logging injury and bark stripping. Proc of Lithuanian Forest Research Institute 33:144-156.

Yilmaz M, Akay AE (2008). Stand damage of a selection cutting system in an uneven aged mixed forest of Çimendagi in Kahramanmaras-Turkey. Int J Nat Eng Sci 2(1):77-82.

Youngblood A (2000). Damaged to residual trees and advanced regeneration from skyline and forwarding yarding in mixedconifer stands of northeastern Oregon. West J Appl For 15(2):101-107. 